\title{
Microgram per Puff
}

National Cancer Institute

\section{Source}

National Cancer Institute. Microgram per Puff. NCI Thesaurus. Code C85704.

Micrograms per puff. 